\title{
Probable ATP-Dependent RNA Helicase DDX10
}

National Cancer Institute

\section{Source}

National Cancer Institute. Probable ATP-Dependent RNA Helicase DDX10. NCI

Thesaurus. Code C97459.

Probable ATP-dependent RNA helicase DDX10 (875 aa, 101 kDa) is encoded by the human DDX10 gene. This protein plays a role in the ATP-dependent unwinding of helical RNA. 